\title{
Capability development and the geographic destination of outbound FDI by developing country firms
}

\author{
Helena Barnard
}

\author{
Gordon Institute of Business Science, \\ University of Pretoria, P.O. Box 787602, \\ Sandton, 2146, South Africa E-mail: \\ barnardh@gibs.co.za
}

\begin{abstract}
This paper uses UNCTAD data to relate the destination of FDI from developing countries to their capability development. It expands the Investment Development Path (IDP) and the flying geese model to include the destination of outward FDI. Investments from developing into developed countries are predominantly in low and medium research-intensive (often considered 'sunset') industries where investors have established strengths in their home base. Developing countries play an active role in knowledge-intensive services in especially the developing world. Even though the developing-country knowledgeintensive firms are not global leaders, their intra-regional FDI enables capability development in emerging industries.
\end{abstract}

Keywords: outbound FDI; developed countries; developing countries; low research-intensity; knowledge-intensive services; Investment Development Path; IDP; flying geese.

Reference to this paper should be made as follows: Barnard, H. (2008) 'Capability development and the geographic destination of outbound FDI by developing country firms', Int. J. Technology and Globalisation, Vol. 4, No. 1, pp.39-55.

\begin{abstract}
Biographical notes: Helena Barnard is currently a Senior Lecturer at the Gordon Institute Business Studies, University of Pretoria, where she teaches innovation, strategy and international business. Her research focuses on economic upgrading in a developing country context, and specifically on the role of foreign knowledge sources.
\end{abstract}

\section{Introduction}

Although the geographic destination of FDI from less developed countries has thus far received little focused academic attention, it has long been noted that developing countries invest not only in other developing countries, but also in more advanced economies (Dunning et al., 1998; Tolentino, 1993). A number of researchers have pointed out that the desire to benefit from the more advanced technological and managerial knowledge of advanced economies, i.e., created asset seeking, has often been an implicit or explicit motive in these investments (Dunning and Wymbs, 1999; Kumar, 1998; Lall, 1983). However, the relationship between firm capabilities and location choice for developing country firms' FDI has not been examined.

This paper offers descriptive data about the location and extent of FDI by developing countries at the end of the 20th century, and demonstrates that there are trends in the location and main industries of FDI. Specifically, it documents that there has been a slowing 
in the rate (although not level) of FDI from less to more developed countries, except in the case of the strongest developing country firms. However, very different types of firms invest in the developed vs. the developing world. Although the most successful developing country firms in the developing world tend to be in knowledge-intensive services, the successful developing country firms in the developed world are in less research-intensive Tow technology' sectors.

The paper is organised as follows: First, the prior literature is reviewed. Then two indicators to determine the extent of FDI by developing countries are presented and discussed, changes in the level of FDI stock and also M\&A activity. Finally, some summary comments are offered.

\section{Prior literature}

The Investment Development Path (IDP) holds that the investment profile of a country is a dynamic reflection of its level of development, and that outbound FDI is characteristic of more developed countries (Dunning, 1981, 1986). A similar model but with a more explicit emphasis on developing countries is the 'flying geese' model (Kojima, 2000; Ozawa, 1992) that addresses the sequential upgrading of Japan, South Korea and other South East Asian countries like Malaysia and the Philippines. In each case, inward FDI, prompted by low wages, set in motion a process of economic development. Yet the inward FDI over time lead to increases in not only economic activity, but also the general level of education and wages, eroding the low-cost locational advantages that initially attracted the FDI. According to the Kojima-Ozawa model, the developing country then initiates outbound FDI to less developed and lower cost locations in order to remain competitive.

Both models see incoming FDI as the initial spur for development, and outbound FDI as a response once countries have achieved a certain level of competitiveness. Although recent research has provided evidence in support of both the flying geese model (Dowling and Cheang, 2000; Ginzberg and Simonazzi, 2005) and IDP (Duran and Ubeda, 2005; Liu et al., 2005), some important refinements have been made. Regarding the flying geese model, the development of export industries, e.g., in electronics, is no longer necessarily preceded by 'import substitution' - firms may be producing for global markets from the outset (Ginzberg and Simonazzi, 2005), suggesting a greater interrelatedness in the global economy. Researchers also consistently find an increase in internationalisation. More than a decade ago already, Tolentino (1993) and Narula (1996) in their work on the IDP find that FDI activity takes place at increasingly lower levels of development.

The shift to a knowledge-based economy has also reduced the importance of the natural resource base and even low wages as sources of comparative advantage. Narula and Dunning point out that "value-added activities have become increasingly knowledge- or information-intensive, not just in high-technology sectors, but also in those that were previously regarded as natural resource or labour-intensive." (Narula and Dunning, 2000, p. 142)

In other words, the motives for FDI have become increasingly complex. The IDP suggests a relatively clear set of motives for FDI with each stage of development: The first stage is characterised by natural resource seeking, the second by increased market seeking, and so on. The search for capabilities - 'created assets' in the formulation of Dunning (1998) - is argued to become important only for developed countries. Similarly, in the flying geese model, outbound FDI by developing countries is spurred by the search for lower costs, not for created assets, and argued to be directed to even lesser-developed countries. The broad 
progression of motives characterised the industrialisation of the current industrial leaders, but in the recent era motives may increasingly co-exist, for example the simultaneous search for natural resources and created assets by Chinese firms (World Investment Report, 2006). By now, a minimum level of competence is needed to attract the most basic of FDI (Lall, 2001). If a threshold level human resource base is necessary for firms that are looking to simply locate low-complexity assembly operations, then it is also necessary to rethink the motives (and given those motives, the most appropriate location) for FDI of firms from countries that are not at the technological frontier.

Research looking at specific multinational corporations from developing countries, rather than general trends, has long documented instances of created asset seeking. Tolentino (1993) confirms the experiential gradual investment pattern first identified by Johanson and Vahlne (1977) and documents that 'third world multinationals' follow a recognisable pattern in their outbound FDI. At first, firms export only to neighbouring and ethnically similar countries. They increasingly expand to non-ethnically related developing countries, until they invest "in countries further away from their home base and in those further away in terms of psychic distance, including developed countries" (Tolentino, 1993, p.364). Such FDI could reflect either the search for markets or the search for capabilities, for example research facilities abroad. Already a decade earlier, in Lall's early work on third world enterprises, he documented evidence of outbound FDI with the aim to access the capabilities of more developed countries:

"There is also a different kind of investment by Hong Kong enterprises emerging: joint ventures in established technology industries which are neither well-established at home nor important export products of the colony. These investments are mainly to find and transfer back manufacturing technologies. As such, they represent something of an exception to the normal pattern of international activity by both developed and developing country enterprises." (Lall, 1983, p.256)

At the time, FDI motivated by the search for capabilities was indeed 'something of an exception' among firms from both developing and developed countries. An analysis of firms from advanced countries reveals a systematic relationship between internationalisation and technical diversification only from about the late 1980s onwards. Cantwell and Piscitello (2000) argue that changes in the business environment, coupled with a shift in the technosocio-economic paradigm are responsible for the change from an ad hoc to a more deliberate linkage between internationalisation and technical diversification. In recent literature, numerous examples of created asset seeking - also termed home base augmenting (Kuemmerle, 1999) or knowledge seeking (Chung and Alcacer, 2002) - have been documented.

Case studies of the 'Asian Tigers' - especially in the collections of Kim and Nelson (2000) and Sachwald (2001) - document the importance of outbound FDI for the upgrading of firms from less developed countries. Outbound FDI to the developed world is seen as key to the success of Samsung's camera business (Lee, 2001), whereas Hyundai's investments in the USA and Japan are seen as final steps in a lengthy, catching-up process that relied on 'crisis construction' to force organisational learning (Kim, 1998). Kim's work makes clear that firms need a threshold level of capabilities to survive in the developed world, suggesting that outbound FDI from less to more developed contexts will tend to be concentrated among the strongest of the developing country firms and firms from relatively more advanced developing countries. At the same time, there has been growing interest in 'South-South' FDI, with considerable effort invested in encouraging developing countries to forge economic relationships with each other (e.g., Sridharan, 1998). 
Yet there is very little generalisable information about the nature or extent of developing countries' FDI to either the developed or developing world. This paper attempts to address this gap in our understanding by examining the destination of FDI from developing countries: Is there a pattern in the location sought by different types of firms? What are the implications in terms of firms' capability development? Two indicators are used to determine the extent of investment by developing countries: First, changes in the levels of FDI stock and second, M\&A activity.

\section{Changes in FDI activity}

The use of FDI data presents a number of challenges. Data on the destination countries for outbound investment are available only for some developing countries, and even for the countries where data are available, only for some years and for some host locations. In order to track changes in the level of FDI from the developing to the developed world, all available information on the location of developing countries' outbound FDI is gathered from UNCTAD, both on the location of developing countries' outbound FDI, and on inbound FDI by less developed countries into the large developed economies, e.g., the USA, UK, Germany, Japan and France. Data on FDI stocks (rather than flows) are used. In the few cases where stock data are not available, the sum of flows is calculated to construct a stock measure (Narula, 1996, p.41).

The data for each country are calculated in dollar terms, and also as a percentage of the total of that country's FDI stock in the developed world and the developed world's FDI stock in that country, i.e., of the FDI that serves to connect the developing country with the technologically more advanced developed world. In order to overcome the problem of irregular data gathering, as well as to account for the fact that many investments are made on a 'piecemeal' basis (Dunning et al., 1998), an average is constructed for three 5-year periods: 1989-1993, 1994-1999 and 2000-2003. The available data are not comprehensive, but provide a reasonable indication of trends in the extent of outbound FDI from less developed countries.

Data are available about the destination of FDI for 30 developing countries, mainly leading countries like Brazil, India, Mexico, Singapore and South Africa. Consistent with what has been elsewhere documented (Dunning et al., 1998), the outward FDI of these developing countries has been consistently rising over the past while. The chart (Figure 1) also indicates that the developed world has long been the largest recipient of FDI from developing countries, and that the level of FDI is steadily rising. Interregional South-South FDI (which is to some extent displacing intraregional FDI) is the fastest growing type of FDI but from a very low base. The chart indicates that even given the continued importance of regional FDI and the rise in interregional South-South FDI, the developed world remains a key recipient of developing countries' FDI. 
Figure 1 Outbound FDI stock of developing countries, 1989-2003 (in millions of US\$)

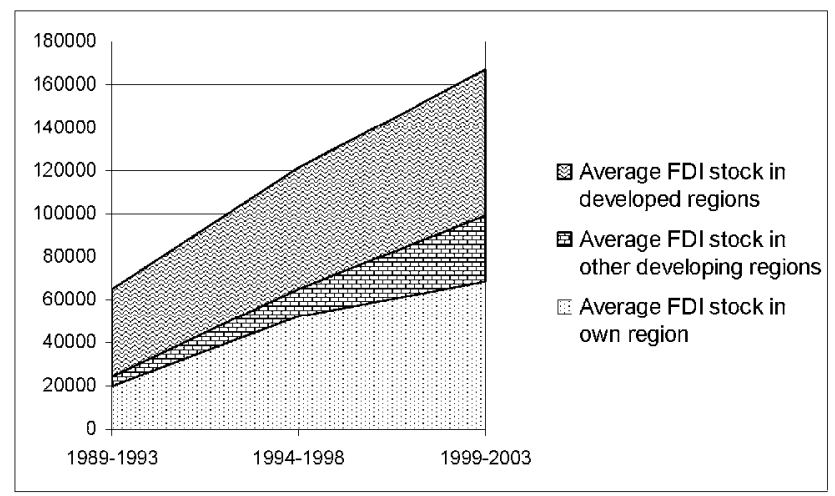

To contextualise the importance of FDI from less to more developed countries, it must be considered against a backdrop of rising FDI activity worldwide. From 1989 to 2003, the levels of FDI of both developed and developing countries increased worldwide. For the same 30 developing countries over the same period, the proportion of FDI from developing to developed countries decreased slightly, and dropped from about $20 \%$ to $15 \%$ of the total FDI stock between the developed and developing world (Table 1). In conclusion, the FDI data seem to suggest that although developing countries investing in more advanced economies occurs in a significant minority of cases, the phenomenon is not seeing rapid growth.

Table 1 FDI stock between developing and developed countries

\begin{tabular}{lccc}
\hline & $1989-1993$ & $1994-1998$ & $1999-2003$ \\
\hline $\begin{array}{l}\text { Total FDI stock from developing to developed } \\
\text { world (in millions of US\$) }\end{array}$ & 40,840 & 55,487 & 66,507 \\
$\begin{array}{l}\text { Total FDI stock from developed to developing } \\
\text { world (in millions of US\$) }\end{array}$ & 145,618 & 231,847 & 399,384 \\
Proportion originating in developing world & $21.90 \%$ & $19.31 \%$ & $14.28 \%$ \\
\hline
\end{tabular}

Source: UNCTAD, country reports and world investment directory

\section{Changes in M\&A activity}

One of the well-documented problems with the use of FDI data is that it is not possible to distinguish between productive investments and capital flight or misclassified portfolio investments (Dunning et al., 1998). For this reason, M\&A activity is an important supplemental indicator. Whether as an attractive target or as the acquirer, a firm involved in a large M\&A can be assumed to be a successful firm with a significant human and capital resource base. In other words, M\&A data capture more than capital flows, and specifically indicate investment in the economic activity of a given sector in a given country. Because specific countries and industries can be identified, a more fine-grained analysis is possible.

Data on all the M\&As that have been recorded in the World Investment Reports from 
1996 (for 1995) to 2006 (for 2005) were collated - the value of each M\&A, and the country and main industry of both the acquired and the acquiring firm. The value of each of these M\&As was in excess of US\$ 1 billion. The M\&As involving developing country firms worth between US\$ 100 million and US\$ 1 billion from the 2005 World Investment Report were also recorded. Countries were designated as developed or developing, following UNCTAD guidelines. The UNCTAD databases identify a firm's country of origin as the country where it has its primary listing. In the few cases where firm listings do not correspond to the country of ultimate ownership, for example where developing country firms have shifted their primary listing to stock exchanges in the developed world, but retain their headquarters and the bulk of their operations in the country of origin (e.g., the South African mining firm Anglo-American) or where firms are listed in well-known tax havens like Bermuda (e.g., the US firm Tyco International) the ultimate beneficiary country was identified and used.

In contrast to the FDI data indicating a slowdown in the rate with which developing countries invest in the developed world, the data for M\&As with a value in excess of US\$ 1 billion suggest a very different picture. Although M\&As with developing country firms as buyers still represent a small minority of M\&As worldwide, the proportion of M\&As where developing country firms act as buyer have been steadily increasing, both in terms of number of transactions, and notably also the dollar value of transactions (see Table 2). This increase is even more pronounced when considered relative to total M\&A activity worldwide (Figure 2). Although increases are seen in the rate with which developing country firms acquire other firms from both the developing and developed world, the fastest growth has been in the acquisition of firms from the developed world.

Developed country firms acquiring firms from developing countries remain the most important mechanism for forging business connections between the developed and developing world, but the proportion of M\&As where developing country firms acquire firms from the developed world has clearly been rising. In fact, when excluding M\&As between firms from developed countries and focusing only on M\&As between the developed and developing world, in the most recent years for which data are available, 2003-2005, acquisitions by developing country firms accounted for more than $40 \%$ of the US\$ value of M\&As.

At least two possible explanations exist for the discrepancy between the FDI and M\&A data. One possibility is simply that the FDI data are unreliable, and that some portion of the FDI data reflects capital flight and portfolio investments. Another possibility is that the relative slowdown of FDI from less to more developed countries is driven by a greater polarisation between more and less developed locations. To the extent that developed countries benefit from an ongoing virtuous cycle of knowledge creation (Cantwell, 1989; Nachum, 2000), developing country firms have to be increasingly capable to thrive or even survive in developed locations. Interestingly, although in 2004 four M\&As worth more than US\$ 1 billion involve developing country firms acquiring firms from the developed world, none are recorded for somewhat smaller transactions - those worth between US\$ 100 million and 1 billion (World Investment Report, 2005). 
Table 2 Developing countries' participation in M\&As worth US\$ 1 billion or more, 1995-2005

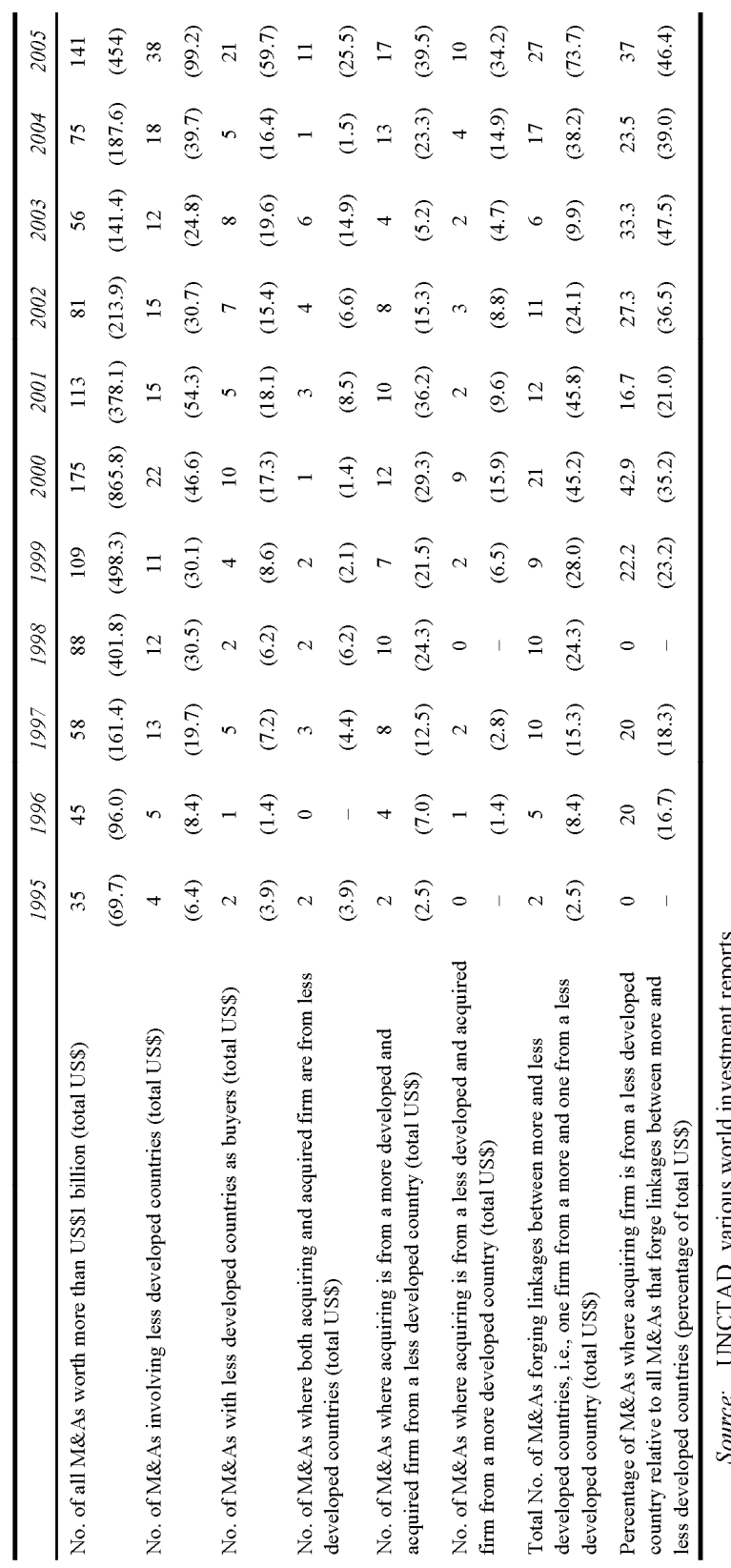


Figure 2 M\&As with developing country firms as buyer as proportion of global large M\&As (in terms of US\$ value of transaction)

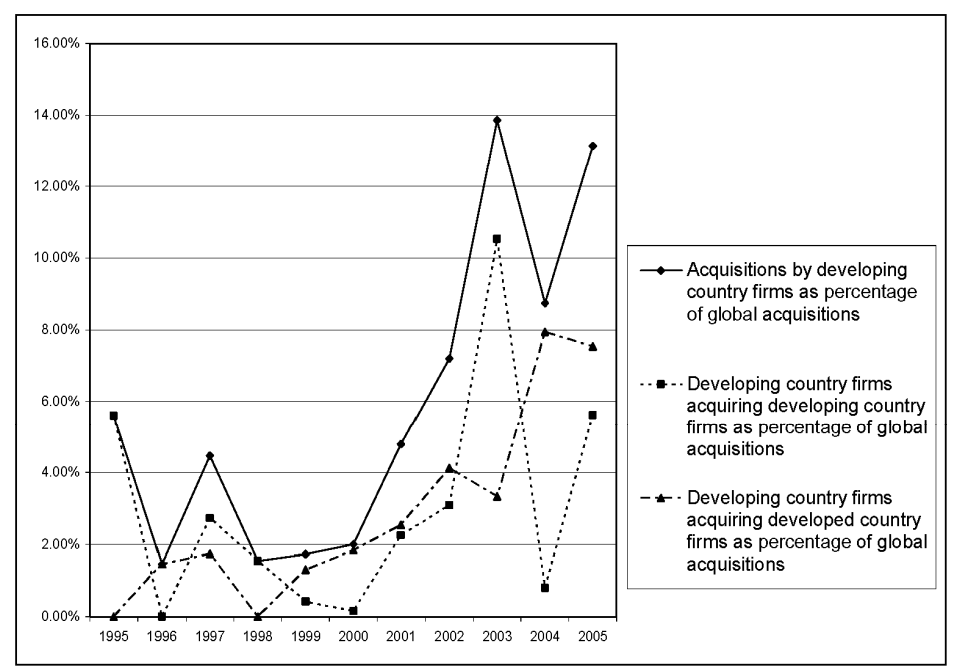

The fact that capability accumulation is cumulative and that more developed locations can accumulate capabilities at a faster rate than elsewhere, could well explain the lower rate at which developing country firms are expanding their investments into the developed world. To be successful in the developed world, increasingly sophisticated capabilities are needed - and at a faster rate than what most developing country firms can develop them. However, it would also suggest that such a firm's decision to invest in the developed world carries greater significance (and potential for learning) than it did one or two decades ago.

In this regard it is interesting to compare the average value of M\&As. It is clear from Tables 2 and 3 that developing countries remain very small participants in the world economy. The number of large M\&As involving less developed countries, whether as buyers or as sellers, is almost never more than $10 \%$ of all the transactions in a given year. Even when developing countries do participate, the size of transactions is on average smaller than for M\&As between developed country firms, although this gap is closing. Whether the size of transactions is increasing because developing country firms are pursuing increasingly attractive targets, or because they are willing to pay a premium for similar quality firms simply because they originate from the developed world, the trend also suggests the increasing importance of the developed world as a host location for developing country firms.

Another important consideration is the types of industries in which developing country firms are active. To make more manageable the wide range of industries that are represented, the sample is coded into the standard categories of Research and Development (R\&D) intensity as used by Dunning (1996) and Lall (1998), expanded to include service industries. Table 4 records the categorisation, based on the average $R \& D$ spending in each industry as per the OECD (Pilat, 2003). 
In coding the industries, there was virtually no evidence of the use of M\&As to facilitate migration between industries. In the few cases where there was backwards or forwards integration, the technological intensity of the destination industry was coded. However, there is clear evidence of specialisation in certain types of industries. In addition, the pattern of specialisation in terms of industries also has a geographical dimension: Different sectors from developing countries tend to invest in the developed rather than the developing world and vice versa.

The dominance of knowledge-intensive services must first be noted. Most M\&As overall over the 11 year period have taken place in knowledge-intensive services, and proportionally speaking, knowledge-intensive services are as important in the developing as the developed world - if not more. This phenomenon is discussed in more detail later.

Table 3 Categorisation in terms of technological intensity (average R\&D spending)

\begin{tabular}{|c|c|}
\hline ISIC 2-digit code & Industries included in each category \\
\hline \multicolumn{2}{|c|}{ Resource-based firms } \\
\hline $01-02$ & Agriculture and forestry \\
\hline 05 & Fishing \\
\hline $10-14$ & Mining \\
\hline \multicolumn{2}{|c|}{ General service firms } \\
\hline $40-41$ & Provision of electricity, gas, water, sewerage etc. \\
\hline 45 & Construction \\
\hline $50-52$ & Wholesale and retail trade \\
\hline 55 & Hotels and restaurants \\
\hline $60-64$ & Transportation and storage \\
\hline $70-71$ & Real estate renting and business activities \\
\hline \multicolumn{2}{|c|}{ Knowledge-intensive service firms } \\
\hline $65-67$ & Financial intermediation, banking, insurance and pension funding \\
\hline $72-74$ & Business services, computing, research and development \\
\hline \multicolumn{2}{|c|}{ Low research intensive manufacturing firms } \\
\hline $15-21$ & $\begin{array}{l}\text { Food products, beverages, textiles, clothing, leather and leather-type } \\
\text { products (e.g., footwear), wood and wood products, paper and paper } \\
\text { products (e.g., printing) }\end{array}$ \\
\hline $36-39$ & Furniture and recycling \\
\hline \multicolumn{2}{|c|}{ Medium research intensive manufacturing firms } \\
\hline $23-29$ & $\begin{array}{l}\text { Refined petroleum products, chemicals and chemical products, rubber } \\
\text { and plastic products, building materials, basic metals and metal products }\end{array}$ \\
\hline 34 & Motor vehicles and other transportation equipment \\
\hline \multicolumn{2}{|c|}{ High research intensive manufacturing firms } \\
\hline $30-33$ & $\begin{array}{l}\text { Machinery and equipment, office, accounting and computing machinery, } \\
\text { electrical machinery, communication equipment, medical, precision and } \\
\text { optical instruments }\end{array}$ \\
\hline 35 & Pharmaceuticals \\
\hline
\end{tabular}


Table 4 Sectoral breakdown of all M\&As worth US\$1 billion and more, 1995-2005

\begin{tabular}{|c|c|c|c|c|c|}
\hline & \multicolumn{2}{|c|}{$\begin{array}{l}\text { Acquiring firm from developing } \\
\text { country investing in }\end{array}$} & \multicolumn{3}{|c|}{$\begin{array}{l}\text { Acquiring firm from developed } \\
\text { country investing in }\end{array}$} \\
\hline & $\begin{array}{l}\text { Developing } \\
\text { countries }\end{array}$ & $\begin{array}{l}\text { Developed } \\
\text { countries }\end{array}$ & $\begin{array}{l}\text { Developing } \\
\text { countries }\end{array}$ & $\begin{array}{l}\text { Developed } \\
\text { countries }\end{array}$ & Total \\
\hline \multicolumn{6}{|l|}{ Resource-based industries } \\
\hline \multirow[t]{2}{*}{ No. of M\&As } & 6 & 4 & 8 & 53 & 71 \\
\hline & $0.6 \%$ & $0.4 \%$ & $0.8 \%$ & $5.4 \%$ & $7.3 \%$ \\
\hline \multirow[t]{2}{*}{ US\$ value (in millions) } & 15 & 9.5 & 26.6 & 280.5 & 331.6 \\
\hline & $0.4 \%$ & $0.3 \%$ & $0.8 \%$ & $8.1 \%$ & $9.6 \%$ \\
\hline \multicolumn{6}{|l|}{ General services } \\
\hline \multirow[t]{2}{*}{ No. of M\&As } & 4 & 8 & 21 & 241 & 274 \\
\hline & $0.4 \%$ & $0.8 \%$ & $2.2 \%$ & $24.7 \%$ & $28.1 \%$ \\
\hline \multirow[t]{2}{*}{ US\$ value (in millions) } & 5.5 & 14.4 & 44.5 & 682.6 & 747 \\
\hline & $0.2 \%$ & $0.4 \%$ & $1.3 \%$ & $19.7 \%$ & $21.5 \%$ \\
\hline \multicolumn{6}{|c|}{ Knowledge-intensive services } \\
\hline \multirow[t]{2}{*}{ No. of M\&As } & 16 & 9 & 51 & 258 & 334 \\
\hline & $1.6 \%$ & $0.9 \%$ & $5.2 \%$ & $26.4 \%$ & $34.2 \%$ \\
\hline \multirow[t]{2}{*}{ US\$ value (in millions) } & 38.4 & 35.8 & 114.9 & 1235 & 1424.1 \\
\hline & $1.1 \%$ & $1.0 \%$ & $3.3 \%$ & $35.6 \%$ & $41.1 \%$ \\
\hline \multicolumn{6}{|c|}{ Low research intensive manufacturing } \\
\hline \multirow[t]{2}{*}{ No. of M\&As } & 6 & 5 & 5 & 67 & 83 \\
\hline & $0.6 \%$ & $0.5 \%$ & $0.5 \%$ & $6.9 \%$ & $8.5 \%$ \\
\hline \multirow[t]{2}{*}{ US\$ value (in millions) } & 11.9 & 19.9 & 11.3 & 205.9 & 249 \\
\hline & $0.3 \%$ & $0.6 \%$ & $0.3 \%$ & $5.9 \%$ & $7.2 \%$ \\
\hline \multicolumn{6}{|c|}{ Medium research intensive manufacturing } \\
\hline \multirow[t]{2}{*}{ No. of M\&As } & 3 & 7 & 8 & 114 & 132 \\
\hline & $0.3 \%$ & $0.7 \%$ & $0.8 \%$ & $11.7 \%$ & $13.5 \%$ \\
\hline \multirow[t]{2}{*}{ US\$ value (in millions) } & 4.2 & 15.9 & 15.7 & 393.8 & 429.6 \\
\hline & $0.1 \%$ & $0.5 \%$ & $0.5 \%$ & $11.4 \%$ & $12.4 \%$ \\
\hline \multicolumn{6}{|c|}{ High research intensive manufacturing } \\
\hline \multirow[t]{2}{*}{ No. of M\&As } & 0 & 2 & 2 & 78 & 82 \\
\hline & $0 \%$ & $0.2 \%$ & $0.2 \%$ & $8 \%$ & $8.4 \%$ \\
\hline \multirow[t]{2}{*}{ US\$ value (in millions) } & 0 & 3.3 & 3.6 & 279.8 & 286.7 \\
\hline & $0 \%$ & $0.1 \%$ & $0.1 \%$ & $8.1 \%$ & $8.3 \%$ \\
\hline \multicolumn{6}{|l|}{ Total } \\
\hline \multirow[t]{2}{*}{ No. of M\&As } & 35 & 35 & 95 & 811 & 976 \\
\hline & $3.6 \%$ & $3.6 \%$ & $9.7 \%$ & $83.1 \%$ & $100 \%$ \\
\hline \multirow[t]{2}{*}{ US\$ value (in millions) } & 75 & 98.8 & 216.6 & 3077.6 & 3468 \\
\hline & $2.2 \%$ & $2.9 \%$ & $6.3 \%$ & $88.7 \%$ & $100 \%$ \\
\hline
\end{tabular}

Source: UNCTAD, various world investment reports (due to rounding, not all totals are exact)

Apart from knowledge-intensive services, whether the acquiring firm is itself a developing country firm, or a firm from the developed world, developing country firms are attractive targets especially for resource-based industries. The importance of resourcebased industries in the developing world is well established, and that firms from developed 
and developing countries alike would decide to seek out resource-bases in other low wage countries is in agreement with prior literature, such as the IDP and flying geese model.

However, a different pattern emerges when looking at developing country firms acquiring firms in the developed world. A fair number of transactions in general services have occurred, confirming the rising importance of services globally (World Investment Report, 2004). But the greatest per transaction dollar amounts involved have been in low and medium research intensive manufacturing. The M\&As of low research intensive firms are in fact the only M\&As involving developing country firms (whether as target or acquirer) where the average value of the transaction is higher than that paid by firms from developed countries. The importance of such Smithian (as opposed to Schumpeterian) industries in less developed countries is well known (Lall, 1998; Ozawa, 1992; Wells, 1983). Given that capability accumulation is cumulative, it is perhaps to be expected that the rate of capability accumulation of developing country firms can keep up better with that of the developed world in this narrow but historically well-established set of industries than in more science-based industries.

The type of prominent developing country firms also raises important questions about the nature of firm learning. Firms in these industries - Cemex, the Mexican cement manufacturer, the Philippine food producer San Miguel, and the South African beer producer SABMiller to name some well-known firms - are characterised by capitalintensive production, scale economies, and assembly-based mass production. In Pavitt's (1984) typology, they tend to follow supplier-dominated or scale-intensive technological trajectories. Formal R\&D typically plays a relatively small role in the capability upgrading of such firms, with production learning and the inputs of suppliers playing a much more important role.

A number of factors are evident when considering lower value M\&As, the 2004 M\&As with a value between US\$ 100 million and 1 billion where developing countries acquire firms from other developing countries (World Investment Report, 2005). First, there are no acquisitions of firms in the developed world, and almost no acquisitions of firms from extra-regional developing countries (Table 5). More modest M\&As by developing country firms are focused almost exclusively in other developing countries in the region, in keeping with Tolentino's (1993) point that the greater the geographical and psychic distance of the investment destination, the greater the capabilities required by the firm. Although the FDI data indicate an increase in South-South FDI, the M\&A data indicate that South-South FDI involves mainly smaller investments.

Even for M\&As below US\$ 1 billion in value, developed countries act as buyers in almost $60 \%$ of the cases, and more if the financial value rather than number of transactions is considered. However, this difference is driven mostly by developed countries' more extensive FDI in manufacturing and resource-based industries. In servicebased industries there is much greater parity in the acquisitions of developed and developing country firms. Part of this parity can be explained by the fact that services, by their nature, are 'location bound' (Boddewyn et al., 1986; Dunning, 1989): They are consumed at the point of production. Although in many industries the advantages of required co-location are being eroded by the fact that service provision is becoming increasingly fragmented and tradable (World Investment Report, 2004), geographically more proximate investors may well retain some advantage over more distant investors. 
Table 5 Sectoral breakdown of all 2004 M\&As involving developing country firms worth between US $\$ 100$ million and 1 billion

\begin{tabular}{|c|c|c|c|c|c|}
\hline & \multicolumn{3}{|c|}{$\begin{array}{l}\text { Acquiring firm from developing } \\
\text { country investing in }\end{array}$} & \multirow[b]{2}{*}{$\begin{array}{c}\text { Acquiring firm from } \\
\text { developed country investing } \\
\text { in developing countries }\end{array}$} & \multirow[b]{2}{*}{ Total } \\
\hline & $\begin{array}{c}\text { Own } \\
\text { developing } \\
\text { region }\end{array}$ & $\begin{array}{l}\text { Other } \\
\text { developing } \\
\text { region }\end{array}$ & $\begin{array}{l}\text { Developed } \\
\text { countries }\end{array}$ & & \\
\hline \multicolumn{6}{|l|}{ Resource-based industries } \\
\hline \multirow[t]{2}{*}{ No. of M\&As } & 1 & 2 & 0 & 8 & 11 \\
\hline & $1 \%$ & $1.9 \%$ & 0 & $7.7 \%$ & $10.6 \%$ \\
\hline \multirow[t]{2}{*}{ US\$ value (in millions) } & 105 & 302 & 0 & 3297 & 3704 \\
\hline & $0.4 \%$ & $1.1 \%$ & 0 & $11.8 \%$ & $13.3 \%$ \\
\hline \multicolumn{6}{|l|}{ General services } \\
\hline \multirow[t]{2}{*}{ No. of M\&As } & 9 & 0 & 0 & 12 & 21 \\
\hline & $8.7 \%$ & 0 & 0 & $11.5 \%$ & $20.2 \%$ \\
\hline \multirow[t]{2}{*}{ US\$ value (in millions) } & 1547 & 0 & 0 & 2891 & 4438 \\
\hline & $5.6 \%$ & 0 & 0 & $10.4 \%$ & $15.9 \%$ \\
\hline \multicolumn{6}{|c|}{ Knowledge-intensive services } \\
\hline \multirow[t]{2}{*}{ No. of M\&As } & 24 & 1 & 0 & 25 & 50 \\
\hline & $23.1 \%$ & $1 \%$ & 0 & $24 \%$ & $48.1 \%$ \\
\hline \multirow[t]{2}{*}{ US\$ value (in millions) } & 6056 & 195 & 0 & 7367 & 13618 \\
\hline & $21.7 \%$ & $0.7 \%$ & 0 & $26.4 \%$ & $48.9 \%$ \\
\hline \multicolumn{6}{|c|}{ Low research intensive manufacturing } \\
\hline \multirow[t]{2}{*}{ No. of M\&As } & 1 & 0 & 0 & 9 & 10 \\
\hline & $1 \%$ & 0 & 0 & $8.7 \%$ & $9.6 \%$ \\
\hline \multirow[t]{2}{*}{ US\$ value (in millions) } & 102 & 0 & 0 & 2036 & 2138 \\
\hline & $0.4 \%$ & 0 & 0 & $7.3 \%$ & $7.7 \%$ \\
\hline \multicolumn{6}{|c|}{ Medium research intensive manufacturing } \\
\hline \multirow[t]{2}{*}{ No. of M\&As } & 3 & 0 & 0 & 3 & 6 \\
\hline & $2.9 \%$ & 0 & 0 & $2.9 \%$ & $5.8 \%$ \\
\hline \multirow[t]{2}{*}{ US\$ value (in millions) } & 431 & 0 & 0 & 889 & 1320 \\
\hline & $1.6 \%$ & 0 & 0 & $3.2 \%$ & $4.7 \%$ \\
\hline \multicolumn{6}{|c|}{ High research intensive manufacturing } \\
\hline \multirow[t]{2}{*}{ No. of M\&As } & 1 & 0 & 0 & 5 & 6 \\
\hline & $1 \%$ & 0 & 0 & $4.8 \%$ & $5.8 \%$ \\
\hline \multirow[t]{2}{*}{ US\$ value (in millions) } & 120 & 0 & 0 & 2536 & 2656 \\
\hline & $0.4 \%$ & 0 & 0 & $9.1 \%$ & $9.5 \%$ \\
\hline \multicolumn{6}{|l|}{ Total } \\
\hline \multirow[t]{2}{*}{ No. of M\&As } & 39 & 3 & 0 & 62 & 104 \\
\hline & $37.5 \%$ & $2.9 \%$ & 0 & $59.6 \%$ & $100 \%$ \\
\hline \multirow[t]{2}{*}{ US\$ value (in millions) } & 8361 & 497 & 0 & 19016 & 27874 \\
\hline & $30 \%$ & $1.8 \%$ & 0 & $68.2 \%$ & $100 \%$ \\
\hline
\end{tabular}

Source: UNCTAD, various World Investment Reports (due to rounding, not all totals are exact)

The increasingly tradable nature of services may explain the generally strong showing of services overall, but still does not explain developing countries' stronger performance in knowledge-intensive services like banking and software rather than general services like 
transportation, retail and real estate. Almost 50\% of all 2004 M\&As in the developing world are in knowledge intensive services, and developing country firms are as likely to act as buyers as firms from the developed world. Although developing country firms play a less prominent role in the developed world, they were also involved in some expensive knowledge-intensive service M\&As in developed countries (Table 4). Clearly, there is tremendous activity in the IT, financial services and telecommunications industries of developing countries.

This focused investment pattern is firstly attributable to the emerging nature of many knowledge-intensive services. Extensive M\&A activity is evident in both the developed and developing world, as firms in these new and increasingly important sectors consolidate. But the active participation of developing country firms can not be simply attributed to consolidation, as developing country firms are (unusually) active and successful in knowledge-intensive service industries. Instead, the phenomenon can probably be explained by the fact that industries evolve in a paradigmatic way.

The socio-techno-economic paradigms within which industries evolve represent a double-edged sword as the requirements for success within a certain paradigm often also constrain actors from fully exploiting the possibilities of a new paradigm. For example, the UK-based system of individual entrepreneurship allowed it to dominate the first industrial (mechanical) revolution, but also constrained its ability to seize leadership during the emergence of the chemicals industry, where a more systematic review of scientific opportunities was central, and where a stronger organisational focus on innovation was therefore needed (Murmann, 2003). In other words, the economic leadership positions of countries are strongly determined by the match between their preexisting capabilities and the capability requirements of an era. This has firstly lead to different countries coming to prominence in different technological eras - with the UK leading the mechanical revolution, Germany and the USA the chemical and electrical revolution, and Japan the electronic era (Cantwell, 1992). Moreover, because of the effects of path dependency, these are also the areas in which the countries retain a strong leadership role. Although countries may struggle to develop capabilities outside of their areas of historical strength, there is a virtuous process of learning that supports capability development within the areas in which they have established technological leadership.

Developing countries must establish themselves in a world in which such technological and economic leadership positions are already well established. The data on the location of their FDI suggests that developing country firms respond in two ways. First, they dynamise their industries in areas of historical strength - commodity-type manufacturing - and displace incumbents in the developed world in those what is sometimes termed 'sunset' industries (Tunzelmann and Acha, 2005).

Second, they develop firms in new and evolving fields where leadership positions have not yet been cemented. Such new fields offer the benefit of industries that are still evolving with relatively fluid leadership positions. Of course, developing countries suffer from a less advanced institutional, educational and economic infrastructure, and their firms are as a rule likely to be less competitive than knowledge-intensive service firms from the developed world. The data indicate that developing country firms still struggle to effectively compete in the developed world, but the knowledge-intensive service firms from developing countries do seem able to keep at bay competitors from the developed world in their own region. Intra-regional FDI offers developing country firms the advantage of geographic and cultural proximity - an advantage that they lose not only when investing in the developed world, but also in extra-regional South-South FDI. 
Still, in emerging industries like telecommunications and IT services, the intra-regional FDI serves as an important entry point for firms wishing to expand their capabilities and enter the global arena.

\section{Conclusion}

Taken together, the data on FDI stock and M\&As suggest a complex picture of developing countries' outbound FDI. First, FDI from less to more developed contexts does not occur only in exceptional cases; the developed world is in fact a key destination of FDI from developing countries. This finding challenges the IDP and flying geese models of the economic development where outbound investment to the developed world receives hardly any attention.

Although investment from developed countries to the developing world remains the most important means of connecting the developed with the developing world, the reverse occurs in a significant minority of cases, suggesting that the relationship between FDI and economic development is more complex than previously argued: Developing countries can and do seek out the more sophisticated markets and technological infrastructure of the developed world. Evidence still points to a systemic relationship between outbound FDI and the level of economic development, so that the changes can probably be related to the increasing interrelatedness of economies. Thus earlier work has indicated that countries engage in outbound FDI earlier than when the IDP was first formulated; this work suggests that not only the level but also the direction of investment is a function of the level of development of investor countries.

Increases in the number of large M\&As and in the average transaction value of M\&As where developing country firms are the acquirer suggest a rise in the importance of investment in the developed world from 1995 to 2005. However, the general rate of growth of FDI from the less to the more developed world has recently been slowing, while extra-regional FDI between developing countries has seen a dramatic increase, albeit from a low base. The combined acceleration in the rate for very large M\&As in the developed world and deceleration in the rate (if not level) of FDI into the developed world generally raises important questions about less powerful developing country firms in the developed world. The developed world seems an increasingly demanding location to do business in, which increases the potential for learning, but also the challenges faced by firms.

There is also a marked split in terms of the types of industries investing in the more and less developed world. Developing country firms in the developed world have a substantial foothold in low and medium research intensive industries. These industries are defined as industries with a relatively lower investment in R\&D, and tend to rely heavily on capital-intensive processing. They are also the types of industries most commonly associated with developing countries. However, because of the commodity-like nature of these industries, they are vulnerable to price pressure and economic cycles.

Developing countries play an unusually active role in knowledge intensive services in both the developed and developing world. Most of developing countries' M\&As activity in the developing world, especially when looking at M\&As with a value of less than US\$ 1 billion, is in knowledge-intensive services, for example telecommunications. Even within knowledge-intensive service firms, a hierarchy of more and less knowledge- 
intensive activities can be identified (Athreye, 2005). Although it is not possible to identify how knowledge-intensive activities are distributed through different developing countries, firms' expansion and the presence of competitors from the developed world clearly trigger a process of evolution and capability development.

In sum, in terms of the capability development of developing country firms, both the developed and the developing world serve important roles. However, the roles are very different. The developed world is the arena for developing country firms in wellestablished Tow' and 'medium' technology industries. FDI in the developed world allows them to assume global leadership positions in their industries. In contrast, developing country firms in the emerging, knowledge-intensive service industries are often overshadowed by firms from the developed world, although they are able to hold their own intra-regionally in the developing world. But although the knowledge-intensive service firms from developing countries are not global leaders, their intra-regional FDI enables the growth and development of firms in these emergent industries. By allowing developing countries to develop expertise in new, less commodity-type industries, such intra-regional FDI serves as an important mechanism for upgrading.

\section{References}

Athreye, S. (2005) 'The Indian software industry and its evolving service capability', Industrial and Corporate Change, Vol. 14, No. 3, pp.393-418.

Boddewyn, J.J., Halbrich, M.B. and Perry, A.C. (1986) 'Service multinationals: conceptualization, measurement and theory', Journal of International Business Studies, Vol. 15, No. 6, Fall, pp.41-57.

Cantwell, J. (Ed.) (1989) 'A classical model of the impact of international trade and production on national industrial growth', Technological Innovation and Multinational Corporations, Basil Blackwell, Oxford, pp. 160-185.

Cantwell, J. (1992) 'Japan's industrial competitiveness and the technological capabilities of the leading Japanese firms', in Arrison, T.S., Bergsten, C.F., Graham, E.M. and Harris, M.C. (Eds.): Japan's Growing Technological Capability: Implications for the US Economy, National Research Council, Washington DC, pp. 165-188.

Cantwell, J. and Piscitello, T. (2000) 'Accumulating technological competence - its changing impact on corporate diversification and internationalisation', Industrial and Corporate Change, Vol. 9, No. 1, pp.21-51.

Chung, W. and Alcacer, J. (2002) 'Knowledge seeking and location choice of foreign direct investment in the United States', Management Science, Vol. 48, No. 12, pp.1534-1554.

Dowling, M. and Cheang, C.T. (2000) 'Shifting comparative advantage in Asia: new tests of the 'flying geese' model', Journal of Asian Economics, Vol. 11, pp.446-463.

Dunning, J.H. (1981) 'Explaining the international direct investment position of countries: towards a dynamic or developmental approach', Weltwirtschaftliches Archiv., Vol. 117, No. 1, pp.30-64.

Dunning, J.H. (1986) 'The investment development cycle revisited', Weltwirtschaftliches Archiv., Vol. 122, No. 4, pp.667-676.

Dunning, J.H. (1989) 'Multinational enterprises and the growth of services: some conceptual and theoretical issues', The Service Industries Journal, Vol. 9, No. 1, pp.5-39.

Dunning, J.H. (1996) 'The geographical sources of the competitiveness of firms: some results of a new survey', Transnational Corporations, Vol. 5, No. 3, pp.1-29.

Dunning, J.H. (1998) 'Location and the multinational enterprise: a neglected factor?', Journal of International Business Studies, Vol. 29, No. 1, pp.45-66.

Dunning, J.H. and Wymbs, C. (1999) 'The geographical sourcing of technology-based assets by 
multinational enterprises', in Archibugi, D., Howells, J. and Michie, J. (Eds.): Innovation Policy in a Global Economy, Cambridge University Press, Cambridge, pp. 185-224.

Dunning, J.H., van Hoesel, R. and Narula, R. (1998) 'Third world multinationals revisited: new developments and theoretical implications', in Dunning, J.H. (Ed.): Globalization, Trade, and Foreign Direct Investment, Elsevier, Amsterdam, pp.255-286.

Duran, J. J. and Ubeda, F. (2005) 'The investment development path of newly developed countries', International Journal of the Economics of Business, Vol. 12, No. 1, pp.123-137.

Ginzberg, A. and Simonazzi, A. (2005) 'Patterns of industrialization and the flying geese model: the case of electronics in East Asia', Journal of Asian Economics, Vol. 15, No. 6, pp.10511078.

Johanson, J. and Vahlne, J.E. (1977) 'The internationalization process of the firm - a model of knowledge development and increasing foreign market commitments', Journal of International Business Studies, Vol. 8, No. 1, pp.23-32.

Kim, L. (1998) 'Crisis construction and organizational learning: capability building in catching-up at hyundai motor corporation', Organization Science, Vol. 9, No. 4, pp.506-521.

Kim, L. and Nelson, R.R. (2000) Technology, Learning, and Innovation, Cambridge University Press, Cambridge.

Kojima, K. (2000) 'The 'flying geese' model of Asian economic development: origin, theoretical extensions, and regional policy implications', Journal of Asian Economics, Vol. 11, pp.375401.

Kuemmerle, W. (1999) 'The drivers of foreign direct investment into research and development: an empirical investigation', Journal of International Business Studies, Vol. 30, No. 1, pp. 1-24.

Kumar, N. (Ed.) (1998) 'Emerging outward foreign direct investment from Asian developing countries: prospects and implications', Globalization, Foreign Direct Investment and Technology Transfers, Routledge, London, pp.177-194.

Lall, S. (1983) The New Multinationals: The Spread of Third World Enterprises, Wiley, Chichester and New York.

Lall, S. (1998) 'Exports of manufactures by developing countries: emerging patterns of trade and location', Oxford Review of Economic Policy, Vol. 14, No. 2, pp.54-73.

Lall, S. (Ed.) (2001) 'What 'competitiveness' is and Why it is important', Competitiveness, Technology, and Skills, Edward Elgar Publishing, Cheltenham, UK, pp. 1-30.

Lee, K-R. (2001) 'Technological catching-up through overseas direct investment: Samsung's camera business', in Sachwald, F. (Ed.): Going Multinational: The Korean Experience of Direct Investment, Routledge, London, pp.275-314.

Liu, X., Buck, T. and Shu, C. (2005) 'Chinese economic development, the next stage: outward FDI?', International Business Review, Vol. 14, pp. 97-115.

Murmann, J.P. (2003) Knowledge and Competitive Advantage: The Coevolution of Firms, Technology, and Institutions, Cambridge University Press, Cambridge.

Nachum, L. (2000) 'Economic geography and the location of TNCs: financial and professional service FDI to the USA', Journal of International Business Studies, Vol. 31, No. 3, pp.367385.

Narula, R. (1996) Multinational Investment and Economic Structure: Globalisation and Competitiveness, Routledge, London.

Narula, R. and Dunning, J.H. (2000) 'Industrial development, globalization and multinational enterprises: new realities for developing countries', Oxford Development Studies, Vol. 28, No. 2, pp.141-167.

Ozawa, T. (1992) 'Foreign direct investment and economic development', Transnational Corporations, Vol. 1, No. 1, pp.27-54.

Pavitt, K. (1984) 'Sectoral patterns of technological change: towards a taxonomy and a theory', Research Policy, Vol. 13, No. 6, pp.343-373. 
Pilat, D. (Ed.) (2003) OECD Science, Technology and Industry Scoreboard, OECD, Paris.

Sachwald, F. (2001) Going Multinational: The Korean Experience of Direct Investment, Routledge, London.

Sridharan, K. (1998) 'G-15 and South-South cooperation: promise and performance', Third World Quarterly,Vol. 19, No. 3, pp.357-373.

Tolentino, P.E. (1993) Technological Innovation and Third World Multinationals, Routledge, London.

Tunzelmann, V. and Acha, V. (2005) 'Innovation in 'low-tech' industries', in Fagerberg, J., Mowery, D.C. and Nelson, R.R. (Eds.): The Oxford Handbook of Innovation, Oxford University Press, Oxford and New York, pp.407-433.

Wells Jr., L.T. (1983) Third World Multinationals: The Rise of Foreign Investment from Developing Countries, MIT Press, Cambridge, MA.

World Investment Report (2004) The Shift to Services, United Nations Council for Trade and Development, New York and Geneva.

World Investment Report (2005) Transnational Corporations and the Internationalization of $R \& D$, United Nations, United Nations Council for Trade and Development, New York and Geneva.

World Investment Report (2006) FDI from Developing and Transition Economies: Implications for Development, United Nations Council for Trade and Development, New York and Geneva. 